\title{
Bacteriological assessment of some vegetables and ready-to-eat salads in Alexandria, Egypt
}

\section{Original Article}

\author{
Amani F. Abaza
}

Department of Microbiology, High Institute of Public Health, Alexandria University, Alexandria, Egypt

\begin{abstract}
Background: Fresh vegetables and ready-to-eat salads (RTES) are essential components of human diet. Despite their benefits, they remain a major public health concern, because they have been implicated in foodborne illness outbreaks in numerous countries.

Aim: The present study aimed to assess the bacteriological quality of some fresh vegetables and RTES in Alexandria, Egypt.

Materials and Methods: This cross-sectional study included 121 samples of vegetables and RTES that were randomly purchased from different markets, restaurants, and street vendors in three districts in Alexandria. All samples were subjected to heterotrophic plate count using pour plate method; detection and enumeration of total coliforms, fecal coliforms and Escherichia coli by multiple tube dilution method; and isolation and detection of Salmonella spp. using standard microbiological methods.

Results: The aerobic colony count (ACC) for the 71 tested fresh vegetable samples ranged from 2.0 to 10.4 log CFU/g. Green pepper had the highest ACC mean value (8.4 log CFU/g), whereas lettuce showed the lowest ACC mean (5.1 log $\mathrm{CFU} / \mathrm{g}$ ). Fecal coliforms were detected in $90.1 \%$ of tested vegetable samples and $66 \%$ of the examined RTES samples. Of the 22 street-vended RTES samples, $18.2 \%$ were significantly unsatisfactory regarding E. coli. Salmonella spp. was not detected in any of the examined samples.

Conclusion: All examined samples were contaminated and yielded growth of aerobic mesophilic bacteria with varying densities. According to the Public Health Laboratories guidelines, only street-vended RTES samples yielded unsatisfactory levels of $E$. coli, which indicates the need for close supervision and regular inspection of hygienic practices and preparation methods of street-vended salads.
\end{abstract}

Received: 30 Sep 2017, Accepted: 27 Oct 2017

Key Words: Aerobic colony count, aerobic mesophilic bacteria, fecal coliforms, microbiological quality, pathogenic organisms, ready-to-eat salads, total coliforms, vegetables

Corresponding Author: Amani F. Abaza, Ph.D., Department of Microbiology, High Institute of Public Health, Alexandria University, Alexandria, Egypt, Tel.:+201005410067,E-mail: amani_abaza@yahoo.com, amani.abaza@alexu.edu.eg

ISSN: 0013-2446, Vol. 92, No.3

\section{INTRODUCTION}

Vegetables are important components of a healthy and balanced diet. They are an extraordinary dietary source of nutrients, micronutrients, vitamins, and fiber for humans and are thus vital for health and well-being ${ }^{[1]}$. Within the past decade and because of intensified public awareness of the benefits of healthy nutrition, attention on vegetables as a vital dietary component has significantly increased their consumption. Moreover, health agencies in many countries as World Health Organization (WHO), European Food Safety Authority (EFSA), Food and Agriculture Organization (FAO), and French Agency for Food Safety (AFSSA) encourage their consumption to protect against a range of illnesses such as cancers and cardiovascular diseases $^{[2]}$.

Vegetables are composed of different range of plant parts (leaves, roots, tubers, fruits, and flowers). A vegetable is the tender plant part that is not sweet and may be flavored or spiced with condiments before consumption. These plants or plant parts may be eaten raw as salad or added to some cooked foods like rice ${ }^{[3]}$.

'Ready to eat' (RTE) is defined as the status of the food being ready for immediate consumption at the point of sale. Ready-to-eat salads (RTES) are low-calorie convenience foods of good dietary value. RTES technology implies procurement of raw vegetables from vertically coordinated farms, cutting, sorting, washing, drying, packaging in permeable plastics, and retailing in cold chain regime. The increased consumption of RTE fresh vegetables, in particular leafy greens, which are used in salad mixtures that are consumed raw, has resulted in increase in foodborne illnesses associated with these products in different regions of the world. They are increasingly being recognized as 
important vehicles for transmission of human pathogens that were traditionally associated with foods of animal $\operatorname{origin}^{[4]}$.

Foodborne illness is a major public health concern worldwide in terms of numbers of persons affected and economic cost. An estimated 600 million - almost one in 10 people in the world - fall ill after eating contaminated food and 420000 die every year, resulting in the loss of 33 million healthy life years ${ }^{[5]}$.

Many foodborne illness outbreaks in numerous countries have been associated with consumption of contaminated fresh vegetables. Hence, many consumers question the quality and safety of these foods. Problems linked with pathogens in fresh produce, including the associated public health and trade implications, have been previously reported in a number of countries worldwide ${ }^{[6]}$. The quality of RTE leafy greens has been surveyed in the United Kingdome (UK) $)^{[7,8]}$ and Brazil ${ }^{[9]}$. Most of the reported foodborne outbreaks originates from Europe, North America, Australia, and New Zealand, as these locations have well-developed epidemiological surveillance systems. In developing countries, paucity of data on food safety together with inaccessibility to safe water, lack of agricultural infrastructures, and limitations to implementing good agricultural practices are persistent challenges ${ }^{[10]}$. Foodborne disease outbreaks originating in prepared raw green vegetable salads were more likely to occur on commercial food service premises than outbreaks from other sources, with restaurants and hotels accounting for almost $75 \%$ of outbreaks. Several outbreaks have been associated with consumption of the products from salad bars $^{[11]}$.

Coliforms are usually indicators of intestinal contaminants from man and animals. This may not be too surprising, as most often the source of watering the gardens is usually sewage from domestic sources and runoff water, which is mostly used for irrigation purposes in some communities. If the counts are high, then they pose dangers to consumers ${ }^{[3]}$. On the other hand, human pathogens such as Escherichia coli (E. coli) and Salmonella spp. are among the greatest concerns during food-related outbreaks. Several cases of typhoid fever outbreaks have been associated with eating contaminated vegetables grown in or fertilized with contaminated soil or sewage ${ }^{[12]}$.

Most people will experience a foodborne disease at some point in their lives. This highlights the importance of making sure the food we eat is not contaminated with potentially harmful microorganisms, toxins, or chemicals. Food can become contaminated at any point during production, distribution, and preparation. Everyone along the production chain, from producer to consumer, has a role to play to ensure the food we eat does not cause diseases ${ }^{[12]}$.
This study was performed to assess the bacteriological quality of some fresh vegetables and ready-to-eat (RTE) vegetable salads collected from local markets, restaurants, and street vendors in Alexandria, Egypt.

\section{MATERIALS AND METHODS}

The present cross-sectional study was carried out during a 4-month period from January to April 2017. It included 121 samples of fresh vegetables (71) and RTE vegetable salads (50) that were randomly purchased from different markets, restaurants, and street vendors in three Alexandria districts, Egypt.

The 71 vegetable samples were distributed as follows: arugula $10(14.1 \%)$, coriander $10(14.1 \%)$, parsley 10 $(14.1 \%)$, celery nine $(12.7 \%)$, dill eight $(11.3 \%)$, lettuce seven $(9.9 \%)$, cucumber six $(8.5 \%)$, green pepper four $(5.6 \%)$, tomato four $(5.6 \%)$, and mint three $(4.2 \%)$ (Table 1). On the other hand, the 50 RTES samples comprised 28 samples from restaurants and 22 samples from street vendors.

\section{Sample size}

Using PASS 2000 Software (Stuart (Bibby Scientific US) Colony Counter SC6PLUSCole-Parmer Ltd. Beacon Road, Stone, Staffordshire, ST15 0SA, United Kingdom Tel: +44 (0)1785810475 Email: cpservice@coleparmer. com Web: www.stuart-equipment.com), a sample size of 100 samples was required to detect a contamination rate of $22 \%{ }^{[13]}$ in vegetables and RTES with unsatisfactory level of aerobic colony count (ACC), with a precision of $8 \%$ at a $95 \%$ confidence level.

\section{Data collection}

Each sample was accompanied by a sheet including all the relevant information such as type and source of sample, date of sampling, site and time of sample collection, place of storage, duration of storage, and temperature of storage.

Every collected sample was properly labeled and transported to the Microbiology Laboratory at the High Institute of Public Health, in an ice box within 1-2 h of collection, where they were processed for bacteriological examination.

\section{Samples processing ${ }^{[14]}$}

Twenty-five grams of each sample was mixed with 225 $\mathrm{ml}$ of sterile buffered peptone water in a sterile stomacher plastic bag and were blended thoroughly in the stomacher for 1-2 min for complete homogenization. This constituted $1: 10$ dilution of the original sample.

All collected samples were subjected to the following: 1- Determination of heterotrophic plate count using pour plate method ${ }^{[14]}$.

Using separate sterile pipettes, decimal dilutions of 
$10^{-2}, 10^{-3}$, and $10^{-4}$ were prepared of food homogenate by transferring $10 \mathrm{ml}$ of previous dilution to $90 \mathrm{ml}$ of diluents, while avoiding sampling foam. All dilutions were shaken 25 times. One $\mathrm{ml}$ of each dilution was pipetted into sterile, separate, appropriately marked, and duplicate Petri dishes. Approximately $12-15 \mathrm{ml}$ of plate count agar (cooled to $45 \pm 1^{\circ} \mathrm{C}$ ) was added to each plate within $15 \mathrm{~min}$ of original dilution. Agar was left to solidify. Then solidified Petri dishes were inverted and incubated promptly for $48 \pm 2 \mathrm{~h}$ at $35^{\circ} \mathrm{C}$. Following the appropriate duration of incubation, colonies were counted using a Quebec digital colony counter. Plates having counts between 25 and 250 colonies were chosen. The average number of colonies/plate was multiplied by the dilution factor and recorded as colony forming unit $(\mathrm{CFU}) / \mathrm{g}$. Bacterial counts were calculated as $\mathrm{CFU} / \mathrm{g}$ and were also converted into $\log _{10}$ values.

\section{2- Detection and enumeration of total coliforms, fecal coliforms, and $E$. coli using multiple tube dilution method ${ }^{[14]}$}

Presumptive test: Using at least three consecutive dilutions, 1-ml aliquots from each dilution were inoculated into three lauryl sulfate tryptose (LST) broths with Durham tubes for a three-tube most probable number (MPN) analysis. Tubes were incubated aerobically at $37^{\circ} \mathrm{C}$. Tubes were examined, and reactions were recorded at $24 \mathrm{~h}$ for turbidity and gas production. Gas-negative tubes were reincubated for an additional $24 \mathrm{~h}$, and reactions were examined and recorded again at $48 \mathrm{~h}$. Confirmation test on all presumptive positive (gas) tubes was performed.

Confirmed test for total coliforms: From each positive LST broth tube, a loopful of suspension was transferred to a tube of brilliant green lactose bile broth. Brilliant green lactose bile broth tubes were incubated at $35 \pm 0.5^{\circ} \mathrm{C}$ and examined for turbidity and gas production at $48 \mathrm{~h}$. MPN of coliforms was calculated.

Confirmed test for fecal coliforms and $\boldsymbol{E}$. coli: From each positive presumptive LST broth tube, a loopful of suspension was transferred to a tube of E. coli broth. Inoculated $E$. coli tubes were incubated at $44.5^{\circ} \mathrm{C}$ and examined for turbidity and gas production at $24 \mathrm{~h}$. Gasnegative tubes were reincubated for an additional $24 \mathrm{~h}$, and reactions were examined and recorded again at $48 \mathrm{~h}$. MPN of thermotolerant coliforms [fecal coliforms (FC)] was calculated.

Completed test for $\boldsymbol{E}$. coli: A loopful of each agitated positive E. coli broth was removed and streaked on a Levine's eosin methylene blue agar plate and incubated aerobically for $24 \mathrm{~h}$ at $35 \pm 0.5^{\circ} \mathrm{C}$. Plates were examined for suspicious $E$. coli colonies, that is, dark centered and flat, with or without metallic sheen. Up to five suspicious colonies from each Levine's eosin methylene blue plate were transferred to plate count agar slants and incubated for $24 \mathrm{~h}$ at $35 \pm 0.5^{\circ} \mathrm{C}$ and used for further testing. They were Gram-stained and tested for indole, methyl red, Voges-Proskauer, and citrate (IMViC) reactions. Isolates that fermented lactose with gas production within $48 \mathrm{~h}$ at $35^{\circ} \mathrm{C}$, appeared as Gram-negative non-spore-forming rods, and were positive for indole and methyl red tests and negative for Voges-Proskauer and citrate tests (biotype 1) or gave IMViC patterns of -+-- (biotype 2) were considered to be $E$. coli.

These isolates were confirmed and further identified using Matrix-Assisted Laser Desorption/Ionization Time of Flight Mass Spectrometry (MALDI TOF MS) test, which was performed in the Microbiology Department at the Faculty of Medicine, Alexandria University.

\section{Isolation and detection of Salmonella spp. ${ }^{[14]}$}

A 0.1-ml mixture of homogenized sample was transferred to 10-ml Rappaport-Vassiliadis medium and another one $\mathrm{ml}$ mixture to $10-\mathrm{ml}$ tetrathionate broth and vortexed. Inoculated selective enrichment media were incubated for $24 \mathrm{~h}$ at $42^{\circ} \mathrm{C}$ in a circulating, thermostatically controlled, water bath. About 3-mm loopful $(10 \mu \mathrm{l})$ of mixed tubes was streaked onto bismuth sulfite agar and xylose lysine deoxycholate agar, and incubated for $24 \mathrm{~h}$ at $35^{\circ} \mathrm{C}$. Pink colonies with or without black centers on xylose lysine deoxycholate and brown, gray, or black colonies with sometimes metallic sheen on bismuth sulfite plates suspicious of being Salmonella spp. were tested using conventional biochemical tests such as triple sugar iron agar, IMViC, urease, arginine, lysine, and ornithine amino acid decarboxylation tests. These isolates were further confirmed and identified using MALDI TOF MS test, which was performed in the Microbiology Department at the Faculty of Medicine, Alexandria University.

\section{Statistical analysis ${ }^{[15]}$}

Data were fed to the computer and analyzed using IBM SPSS software package, version 20.0. (IBM Corp, Armonk, New York, USA). The Kolmogorov-Smirnov, Shapiro, and D'agstino tests were used to verify the normality of distribution of variables. Comparisons between groups for categorical variables were assessed using $\chi 2$-test. KruskalWallis test was used to compare different groups for abnormally distributed quantitative variables and followed by post-hoc test (Dunn's multiple comparisons test) for pairwise comparison. Significance of the obtained results was judged at the $5 \%$ level.

\section{RESULTS}

In the present study, the 121 collected samples included $71(58.6 \%)$ fresh vegetables purchased from different markets located in the three Alexandria districts, together with 50 RTE vegetable salads bought from restaurants and street vendors [28 (23.1\%) and $22(18.2 \%)$, respectively]. All examined samples $(100 \%)$ were contaminated and yielded aerobic mesophilic bacteria of varying densities. The ACC for the 71 examined fresh vegetable samples ranged from 2.0 to $10.4 \log \mathrm{CFU} / \mathrm{g}$, with a median of 7.08 and a mean value of $6.76 \pm 1.94$. Regarding the 28 RTES samples collected from restaurants, ACC ranged from 
3.8 to $9.4 \log \mathrm{CFU} / \mathrm{g}$, with a median of 7.7 and a mean of $7.5 \pm 1.4$, whereas the 22 RTES samples purchased from street vendors had an ACC range of 2.7-5.9 log CFU/g, a median of 3.8 and a mean of $4.1 \pm 1.0$ (Table 1 ).

Green pepper had the highest ACC mean value (8.4 $\pm 2.0 \log \mathrm{CFU} / \mathrm{g}$ ), followed by parsley $(7.9 \pm 1.0$ $\log \mathrm{CFU} / \mathrm{g})$, arugula $(7.7 \pm 1.9 \quad \log \mathrm{CFU} / \mathrm{g}), \quad \mathrm{mint}$ $(7.7 \pm 1.0 \log \mathrm{CFU} / \mathrm{g})$, and coriander $(6.5 \pm 2.0 \mathrm{log} \mathrm{CFU} / \mathrm{g})$. The lowest ACC mean value was recorded for lettuce samples $(5.1 \pm 1.4 \log$ CFU/g) (Table 1).

Table 1 also displays that the 71 tested fresh vegetables had a mean value for total coliforms (TC) of $4.15 \pm 0.0 \mathrm{log}$ MPN/100 g. On the other hand, FC mean values ranged between 3.0 and $4.1 \log$ MPN/100 g, where arugula, cucumber, and mint showed the highest FC mean values (4.1 log MPN/100 g each), and tomato samples had the lowest mean (3.0 log MPN/100 g). There was no statistical significant difference between any of these figures.

Table 1: Distribution of 71 examined fresh vegetables and their ACC, TC ${ }^{\#}$, and FC mean and median values

\begin{tabular}{|c|c|c|c|c|c|}
\hline Vegetables $(\mathrm{n}=71)$ & $\mathrm{n}(\%)$ & $\begin{array}{c}\text { Aerobic colony } \\
\text { count (ACC) } \\
(\log \text { CFU/g) }\end{array}$ & $\begin{array}{l}\text { Aerobic colony count } \\
\quad(\text { ACC })(\mathrm{CFU} / \mathrm{g})\end{array}$ & $\begin{array}{l}\text { Fecal coliforms } \\
\text { (FC) (log } \\
\text { MPN/100 g) }\end{array}$ & $\begin{array}{l}\text { Fecal coliforms } \\
\text { (FC) }(\mathrm{MPN} / 100 \mathrm{~g})\end{array}$ \\
\hline \multicolumn{6}{|l|}{ Arugula } \\
\hline Mean \pm SD & $10(14.1)$ & $7.7 \mathrm{a} \pm 1.9$ & $3 \times 10^{9} \mathrm{a} \pm 3 \times 10^{5}$ & $4.1 \mathrm{a} \pm 0.3$ & $1 \times 10^{4} \mathrm{a} \pm 3 \times 10^{3}$ \\
\hline Median (minimum-maximum) & & $7.6(3.8-10.2)$ & $4 \times 10^{7}\left(6 \times 10^{3}-2 \times 10^{10}\right)$ & $4.1(3.3-4.1)$ & $14 \times 10^{3}\left(2 \times 10^{3}-14 \times 10^{3}\right)$ \\
\hline \multicolumn{6}{|l|}{ Coriander } \\
\hline Mean \pm SD & $10(14.1)$ & $6.5 \mathrm{a} \pm 2.0$ & $2 \times 10^{8} \mathrm{a} \pm 4 \times 10^{8}$ & $3.9 \mathrm{a} \pm 0.4$ & $1 \times 10^{3} \mathrm{a}, \mathrm{b} \pm 5 \times 10^{3}$ \\
\hline Median (minimum-maximum) & & $6.9(3.8-9.1)$ & $2 \times 10^{7}\left(6 \times 10^{3}-11 \times 10^{8}\right)$ & $4.1(3-4.1)$ & $14 \times 10^{3}\left(950-14 \times 10^{3}\right)$ \\
\hline \multicolumn{6}{|l|}{ Parsley } \\
\hline Mean \pm SD & $10(14.1)$ & $7.9 \mathrm{a} \pm 1.0$ & $5 \times 10^{8} \mathrm{a} \pm 1 \times 10^{9}$ & $3.6 \mathrm{a} \pm 1.2$ & $9 \times 10^{3} \mathrm{ab} \pm 5 \times 10^{3}$ \\
\hline Median (minimum-maximum) & & $7.9(6.5-9.6)$ & $7 \times 10^{7}\left(3 \times 10^{6}-4 \times 10^{9}\right)$ & $4.1(3-4.1)$ & $14 \times 10^{3}\left(2-14 \times 10^{3}\right)$ \\
\hline \multicolumn{6}{|l|}{ Celery } \\
\hline Mean \pm SD & $9(12.7)$ & $6.2 \mathrm{a} \pm 2.3$ & $2 \times 10^{8} \mathrm{a} \pm 4 \times 10^{8}$ & $3.6 \mathrm{a} \pm 0.7$ & $7 \times 10^{3} \mathrm{a}, \mathrm{b} \pm 6 \times 10^{3}$ \\
\hline Median (minimum-maximum) & & $6.8(3.8-9.0)$ & $7 \times 10^{6}\left(6 \times 10^{3}-11 \times 10^{8}\right)$ & $4.0(2.5-4.1)$ & $11 \times 10^{3}\left(300-14 \times 10^{3}\right)$ \\
\hline \multicolumn{6}{|l|}{ Dill } \\
\hline Mean \pm SD & $8(11.3 \%)$ & $5.8 \mathrm{a} \pm 1.6$ & $2 \times 10^{7} a \pm 6 \times 10^{7}$ & $3.8 \mathrm{a} \pm 0.6$ & $10 \times 10^{3} \mathrm{a}, \mathrm{b} \pm 6 \times 10^{3}$ \\
\hline Median (minimum-maximum) & & $6.1(3.8-8.2)$ & $2 \times 10^{6}\left(6 \times 10^{3}-2 \times 10^{8}\right)$ & $4.1(2.6-4.1)$ & $14 \times 10^{3}\left(400-14 \times 10^{3}\right)$ \\
\hline \multicolumn{6}{|l|}{ Lettuce } \\
\hline Mean \pm SD & $7(9.9 \%)$ & $5.1 \mathrm{a} \pm 1.4$ & $7 \times 10^{6} \mathrm{a} \pm 2 \times 10^{7}$ & $4.0 \mathrm{a} \pm 0.2$ & $8 \times 10^{3} \mathrm{a}, \mathrm{c} \pm 6 \times 10^{3}$ \\
\hline Median (minimum-maximum) & & $4.6(3.8-7.7)$ & $4 \times 10^{4}\left(6 \times 10^{3}-\mathrm{s} \times 10^{7}\right)$ & $4.1(3.7-4.1)$ & $11 \times 10^{3}\left(0-14 \times 10^{3}\right)$ \\
\hline \multicolumn{6}{|l|}{ Cucumber } \\
\hline Mean \pm SD & $6(8.5 \%)$ & $5.9 \mathrm{a} \pm 2.1$ & $1 \times 10^{7} \mathrm{a} \pm 1 \times 10^{7}$ & $4.1 \mathrm{a} \pm 0.1$ & $8 \times 10^{3} \mathrm{a}, \mathrm{c} \pm 6 \times 10^{3}$ \\
\hline Median (minimum-maximum) & & $6.4(2.0-7.5)$ & $1 \times 10^{7}\left(103-3 \times 10^{7}\right)$ & $4.1(4-4.1)$ & $11 \times 10^{3}\left(0-14 \times 10^{3}\right)$ \\
\hline \multicolumn{6}{|l|}{ Green pepper } \\
\hline Mean \pm SD & $4(5.6)$ & $8.4 \mathrm{a} \pm 2.0$ & $7 \times 10^{9} \mathrm{a} \pm 1 \times 10^{10}$ & $3.6 \mathrm{a} \pm 0.8$ & $6 \times 10^{3} \mathrm{~b}, \mathrm{c} \pm 7 \times 10^{3}$ \\
\hline Median (minimum-maximum) & & $8.6(5.8-10.4)$ & $1 \times 10^{9}\left(6 \times 10^{5}-83 \times 10^{10}\right)$ & $4.1(2.7-4.1)$ & $5 \times 10^{3}\left(0-14 \times 10^{3}\right)$ \\
\hline \multicolumn{6}{|l|}{ Tomato } \\
\hline Mean \pm SD & $4(5.6)$ & $7.6 \mathrm{a} \pm 0.9$ & $1 \times 10^{8} \mathrm{a} \pm 2 \times 10^{8}$ & $3.0 \mathrm{a} \pm 0.6$ & $850 \mathrm{c} \pm 1 \times 10^{3}$ \\
\hline Median (minimum-maximum) & & $7.5(6.8-8.6)$ & $9 \times 10^{7}\left(7 \times 10^{6}-4 \times 10^{8}\right)$ & $3.0(2.6-3.5)$ & $200(0-3000)$ \\
\hline \multicolumn{6}{|l|}{ Mint } \\
\hline Mean \pm SD & $3(4.2)$ & $7.7 \mathrm{a} \pm 1.0$ & $2 \times 10^{8} \mathrm{a} \pm 4 \times 10^{8}$ & $4.1 \mathrm{a} \pm 0.1$ & $13 \times 10^{3} \mathrm{a}, \mathrm{b} \pm 1 \times 10^{3}$ \\
\hline Median (minimum-maximum) & & $7.3(7.0-8.8)$ & $2 \times 10^{7}\left(9 \times 10^{6}-7 \times 10^{8}\right)$ & $4.1(4-4.1)$ & $14 \times 10^{3}\left(11 \times 10^{3}-14 \times 10^{3}\right)$ \\
\hline$P$ & & 0.053 & 0.053 & 0.368 & 0.042 \\
\hline
\end{tabular}

Qualitative data were described using number and percent, whereas abnormally distributed data were expressed in median (minimummaximum) and mean $\pm \mathrm{SD}$; ACC, aerobic colony count; CFU, colony forming unit; FC, fecal coliforms; MPN, most probable number; TC, total coliforms; Means with common letters are not significant, whereas means with different letters are significant; ${ }^{\# A l l ~} 71$ tested vegetables had total coliforms mean values of $4.15 \pm 0.01 \log$ MPN/100 g; ${ }^{\#}$ As the botanical term vegetable is defined as the edible part(s) of a plant, such as fruits; tomato is considered a vegetable, and it is an essential ingredient in the Egyptian green salad. 
Table 2 illustrates that the ACC mean value of the 71 tested vegetables was $6.76 \pm 1.94 \log \mathrm{CFU} / \mathrm{g}$, whereas the corresponding figures for RTES from restaurants and street vendors were $7.5 \pm 1.4$ and $4.1 \pm 1.0 \log \mathrm{CFU} / \mathrm{g}$, respectively. There was a statistical significant difference between vegetables and RTES from street vendors $\left(P_{2}<0.001\right)$ and between RTES from restaurants and street vendors $\left(P_{3}<0.001\right)$.

The mean value of TC for the examined vegetables and RTES from restaurants was $4.15 \pm 0.0 \log$ MPN/100 g each, whereas a lower value was recorded for RTES from street vendors $(4.04 \pm 0.31 \log$ MPN/100 g). The difference between vegetables and RTES from street vendors was found to be statistically significant $\left(P_{2}=0.002\right)$. Moreover, the difference between RTES from restaurants and street vendors was also found to be statistically significant $\left(P_{3}=0.046\right)$ (Table 2).

FC were detected in $64(90.1 \%)$ of 71 tested vegetable samples. On the other hand, of the 50 examined RTES samples, $33(66 \%)$ were positive for FC. They were distributed as $15(30.0 \%)$ samples from restaurants and 18 $(36.0 \%)$ samples from street vendors.

FC mean values for vegetables, RTES from restaurants, and street vendors were $3.81 \pm 0.67,4.44 \pm 1.64$ and $2.85 \pm 1.02 \log$ MPN/100 g, respectively. There was a statistical significant difference between vegetables and RTES from street vendors $(\mathrm{P} 2<0.001)$ and between RTES from restaurants and street vendors $(\mathrm{P} 3=0.010)$ (Table 2$)$.

Table 2: Comparison between 121 examined fresh vegetables and RTES regarding ACC, TC and FC mean and median values

\begin{tabular}{|c|c|c|c|c|}
\hline & \multicolumn{3}{|c|}{ Ready to eat salads (RTES) $(n=50)$} & \multirow[b]{2}{*}{$P$} \\
\hline & Vegetables $(n=71)$ & Restaurants $(\mathrm{n}=28)$ & Street vendors $(n=22)$ & \\
\hline \multicolumn{5}{|l|}{ Aerobic colony count $(\log \mathrm{CFU} / \mathrm{g})$} \\
\hline Mean \pm SD & $6.76 \pm 1.94$ & $7.5 \pm 1.4$ & $4.1 \pm 1.0$ & $<0.001^{*}$ \\
\hline Median (minimum-maximum) & $7.08(2.0-10.4)$ & $7.7(3.8-9.4)$ & $3.8(2.7-5.9)$ & \\
\hline Significance between groups & \multicolumn{4}{|c|}{$P_{1}=0.092, P_{2}<0.001 *, P_{3}<0.001 *$} \\
\hline \multicolumn{5}{|l|}{ Total coliforms $(\log$ MPN/100 g) } \\
\hline Mean \pm SD & $4.15 \pm 0.0$ & $4.15 \pm 0.0$ & $4.04 \pm 0.31$ & $0.001^{*}$ \\
\hline Median (minimum-maximum) & $4.15(4.15-4.15)$ & $4.15(4.15-4.15)$ & $4.15(2.98-4.15)$ & \\
\hline Significance between groups & \multicolumn{4}{|c|}{$P_{1}=1.000, P_{2}=0.002^{*}, P_{3}=0.046^{*}$} \\
\hline Fecal coliforms $(\log$ MPN/100 g) & $\mathrm{n}=64$ & $\mathrm{n}=15$ & $\mathrm{n}=18$ & \\
\hline Mean \pm SD & $3.81 \pm 0.6$ & $4.44 \pm 1.64$ & $2.85 \pm 1.02$ & $0.001^{*}$ \\
\hline Median (minimum-maximum) & $4.15(0.30-4.15)$ & $5.04(1.60-6.15)$ & $2.53(1.60-4.15)$ & \\
\hline Significance between groups & \multicolumn{4}{|c|}{$P_{1}=0.265, P_{2}<0.001 *, P_{3}=0.010^{*}$} \\
\hline
\end{tabular}

Abnormally distributed data were expressed in median (minimum-maximum)

$P_{l}: P$ value for comparing between vegetables and RTES from restaurants.

$P_{2}: P$ value for comparing between vegetables and RTES from street vendors.

$P_{3}: P$ value for comparing between RTES from restaurants and street vendors.

ACC, aerobic colony count; CFU, colony forming unit; FC, fecal coliforms; MPN, most probable number; RTES, ready-to-eat salads; TC, total coliforms.

*Statistically significant at $P \leq 0.05$ 
Table 3 shows that all the $22(100 \%)$ RTES samples obtained from street vendors were satisfactory regarding ACC, while of the 28 RTES samples collected from restaurants, 13 (46.4\%) were acceptable with ACC ranging between $10^{6}$ and less than $10^{7} \mathrm{CFU} / \mathrm{g} ; 10$ (35.7\%) were unsatisfactory, with an ACC equal to or more than $10^{7}$ $\mathrm{CFU} / \mathrm{g}$; and only five (17.9\%) were satisfactory, with an ACC of less than $10^{6} \mathrm{CFU} / \mathrm{g}$. The difference between these figures was found to be statistically significant $(P<0.001)$. All 71 fresh vegetable samples together with all RTES
(28) samples from restaurants were satisfactory regarding E. coli $(<20 \mathrm{CFU} / \mathrm{g})$. On the other hand, 18/22 (81.8\%) RTES samples from street vendors were satisfactory and only four $(18.2 \%)$ were unsatisfactory $(>100 \mathrm{CFU} / \mathrm{g})$. The difference between these figures was found to be statistically significant $\left(P_{2}=0.003, P_{3}=0.032\right)$ (Table 3$)$.

In this piece of work, all the 121 studied samples were satisfactory regarding Salmonella spp. as it was not detected in $25 \mathrm{~g}$ of any of these samples (Table 3).

Table 3: Microbiological quality of the 121 studied fresh vegetables and ready-to-eat vegetable salads according to the Public Health Laboratories guidelines $^{[17]}$

Ready-to-eat salads (RTES) (n=50)

\begin{tabular}{|c|c|c|c|c|c|}
\hline & $\begin{array}{l}\text { Vegetables } \\
\quad(\mathrm{n}=71)\end{array}$ & $\begin{array}{l}\text { Restaurants } \\
(\mathrm{n}=28)\end{array}$ & $\begin{array}{l}\text { Street vendors } \\
\quad(\mathrm{n}=22)\end{array}$ & $\begin{array}{c}\text { RTES } \\
(\mathrm{n}=50) \\
\text { total }\end{array}$ & $P$ \\
\hline \multicolumn{6}{|l|}{ Aerobic colony count } \\
\hline Satisfactory $\left(<10^{6} \mathrm{CFU} / \mathrm{g}\right)$ & NA & $5(17.9)$ & $22(100.0)$ & $27(54.0)$ & \multirow[t]{3}{*}{$<0.001 *$} \\
\hline Acceptable $\left(10^{6}\right.$ to $\left.<10^{7} \mathrm{CFU} / \mathrm{g}\right)$ & NA & $13(46.4)$ & $0(0.0)$ & $13(26)$ & \\
\hline Unsatisfactory $\left(\geq 10^{7} \mathrm{CFU} / \mathrm{g}\right)$ & NA & $10(35.7)$ & $0(0.0)$ & $10(20.0)$ & \\
\hline \multicolumn{6}{|l|}{ E. coli } \\
\hline Satisfactory $(<20 \mathrm{CFU} / \mathrm{g})$ & $71(100)$ & $28(100.0)$ & $18(81.8)$ & - & \multirow[t]{3}{*}{$0.001 *$} \\
\hline Unsatisfactory $(>100 \mathrm{CFU} / \mathrm{g})$ & $0(0)$ & $0(0)$ & $4(18.2)$ & - & \\
\hline Significance between groups & \multicolumn{4}{|c|}{$P_{1}=\mathrm{NA}, P_{2}=0.003 *, P_{3}=0.032 *$} & \\
\hline \multicolumn{6}{|l|}{ Salmonella spp. } \\
\hline Satisfactory (not detected in $25 \mathrm{~g}$ ) & $71(100)$ & $28(100.0)$ & $22(100.0)$ & - & - \\
\hline Unacceptable/potentially hazardous (detected in $25 \mathrm{~g}$ ) & $0(0)$ & $0(0)$ & $0(0)$ & - & \\
\hline
\end{tabular}

Satisfactory=test results indicating good microbiological quality.

Acceptable $=$ an index reflecting a borderline limit of microbiological quality.

Unsatisfactory=test results indicating that further sampling may be necessary and that environmental health officers may wish to undertake a further inspection of the premises concerned to determine whether hygiene practices for food production or handling are adequate or not.

Unacceptable/potentially hazardous=test results indicating that urgent attention is needed to locate the source of the problem; a detailed risk assessment is recommended.

Qualitative data were described using $\mathrm{n}(\%)$.

P1: $P$ value for comparing between vegetables and RES from restaurants.

$P 2: P$ value for comparing between vegetables and RES from street vendors.

P3: $P$ value for comparing between RES from restaurants and street vendors.

CFU, colony forming unit; NA, not applicable; RES, ready to eat; RTES, ready-to-eat salads.

*Statistically significant at $\mathrm{P} \leq 0.05$

\section{DISCUSSION}

Global production and consumption of fresh vegetables has been increasing for the past three decades. This is because of the increased demand for healthy food that ensures sufficient intake of minerals, fibers, and vitamins with antimicrobial properties, and it also decreases the risk of cardiovascular diseases, cancer, and stroke ${ }^{[6]}$.
In addition, it has become well documented that there is an increased outdoor consumption of RTES as a result of a fast-paced lifestyle, awareness on their nutritional benefits, and enhanced processing technology. However, when they are not carefully prepared, they can be subjected to microbial contamination and become hazardous to health, particularly when eaten raw ${ }^{[10]}$. 
Microbial safety of vegetables and RTES is currently a global concern. The present study aimed to evaluate the bacteriological quality of some fresh vegetables and RTES in Alexandria, Egypt; as fresh vegetables and mixed vegetable salads constitute an essential and indispensable component of most of the Egyptians' daily diet.

This work included 121 samples distributed as 71 (58.6\%) fresh vegetables and 50 (41.3\%) RTE mixed vegetable salads. All these samples yielded growth of aerobic mesophilic bacteria with varying densities. It has been documented that aerobic organisms reflect the exposure of samples to any contamination and generally the existence of favorable conditions for microorganisms' multiplication.

The acceptable ACC limit of fresh vegetables by some countries for export purposes should not exceed $6.69 \mathrm{log}$ $\mathrm{CFU} / \mathrm{g}^{[17]}$. The ACC of the 71 examined fresh vegetable samples in this study showed a wide range of microbial load from 2.0 to $10.4 \log \mathrm{CFU} / \mathrm{g}$, with a median of 7.08 and a mean of $6.76 \pm 1.94 \mathrm{log} C F U / g$. This was in line with the findings of Faour-Klingbeil et al. ${ }^{[10]}$ in Lebanon who reported that the mean ACC levels ranged from 2.90 to $7.38 \log \mathrm{CFU} / \mathrm{g}$, with counts above $10^{7} \mathrm{CFU} / \mathrm{g}$ recorded for $17 \%$ of their samples. Furthermore, in accordance with the present results, Khalil and Gomaa ${ }^{[18]}$ in Egypt recorded a wide range of aerobic mesophilic count (AMC) for conventional vegetable samples (3.63-7.17 log CFU/g). On the other hand, Weldezgina and Muleto in Ethiopia ${ }^{[19]}$ and Nyenje et al. ${ }^{[20]}$ in South Africa observed narrower ranges of high $\mathrm{AMC}$ from 6.94 to 8.06 and from 6.3 to 6.8 $\log \mathrm{CFU} / \mathrm{g}$, respectively). A much lower AMC range of 2.95-3.75 log CFU/g was reported by Buyukunal et al. ${ }^{[21]}$ in Turkey. The difference in the ACC mean values may be attributed to the different areas of vegetables cultivation and different irrigation sources. It has been noted that plate count of aerobic mesophilic microorganisms found in food is one of the microbiological indicators for food quality, and most foods are regarded as harmful when they have large populations of these microorganisms, even if the organisms are not known to be pathogens ${ }^{[22]}$.

In this study, green pepper had the highest ACC mean value $(8.4 \pm 2.0 \mathrm{log} \mathrm{CFU} / \mathrm{g})$, followed by parsley (7.9 $\pm 1.0 \log \mathrm{CFU} / \mathrm{g})$, arugula $(7.7 \pm 1.9 \mathrm{log} \mathrm{CFU} / \mathrm{g})$, mint $(7.7 \pm 1.0 \log \mathrm{CFU} / \mathrm{g})$, and coriander $(6.5 \pm 2.0 \mathrm{CFU} / \mathrm{g})$. A higher count of parsley was recorded in Lebanon by Halablab et al. ${ }^{[23]}$, where the total aerobic plate count of parsley samples collected from Barelias ranged from 8.3 to $9.85 \log 10 \mathrm{CFU} / \mathrm{g}$. However, Faour-Klingbeil et $a .^{[10]}$ found that of the 118 examined fresh-cut vegetable samples, coriander had the highest mean count of 7.38 $\pm 0.00 \mathrm{log}$ CFU/g, followed by lettuce $(5.50 \pm 1.55 \mathrm{log}$ $\mathrm{CFU} / \mathrm{g})$, parsley $(5.42 \pm 1.32 \mathrm{log} \mathrm{CFU} / \mathrm{g})$, radish $(5.09 \pm 2.2$ $\log \mathrm{CFU} / \mathrm{g})$, cucumber $(4.60 \pm 2.01 \log \mathrm{CFU} / \mathrm{g})$, and arugula (3.99 $\pm 2.44 \log \mathrm{CFU} / \mathrm{g})$. In contrast to the present results, Khalil and Gomaa ${ }^{[16]}$ reported that the maximum
AMC mean value was obtained from radish $(7.17 \pm 2.8$ $\log \mathrm{CFU} / \mathrm{g})$, followed by basil and mint $(6.88 \pm 0.23$ and $6.77 \pm 0.53 \log \mathrm{CFU} / \mathrm{g}$, respectively).

Furthermore, in the current work, the lowest ACC mean

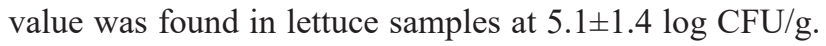
This was in agreement with Khalil and Gomaa ${ }^{[18]}$ who found that lettuce had the lowest mean AMC (3.15 \pm 0.46 $\log \mathrm{CFU} / \mathrm{g})$. On the contrary, Buyukunal et al..$^{[21]}$ in Turkey reported that green leaf lettuce, iceberg lettuce, cos lettuce, and spinach had significantly higher microbial loads than other tested commodities. Moreover, Halablab et al. ${ }^{[23]}$ in Lebanon documented that all lettuce samples collected from different locations in Bekaa Valley had higher incidence of aerobic organisms than any other vegetable samples collected from the same locations. In Barelias, for instance, the aerobic bacterial count on lettuce ranged from 8.0 to $10.4 \log 10 \mathrm{CFU} / \mathrm{g}$ compared with Rawda (El Establ), Jib-Janine, and Kaaroun, where the aerobic counts were 8.0-9.27, 7.17, and $6.75 \log 10 \mathrm{CFU} / \mathrm{g}$, respectively.

Indicator bacteria may be associated with an increased likelihood of the presence of pathogens. They are useful in the assessment of food product safety because they tend to be present in higher numbers than most pathogens and are relatively quick and easy to identify ${ }^{[24]}$. In the present study, all 71 tested vegetables had TC mean values of $4.15 \pm 0.0 \log$ MPN/100 g. This agreed with the findings of Nguz et al. ${ }^{[25]}$, who showed that mixed vegetables were still found to harbor high levels of TC (5.9 log CFU/g). High loads of coliforms in RTE vegetables at retail levels can be directly influenced by intense use of untreated manure during preharvest and extensive handling during postharvest $^{[22]}$.

Results of FC in this study exhibited the presence of fecal contamination in $90.1 \%$ of the examined fresh vegetable samples. FC mean values ranged between 850 and $1 \times 10^{4} \mathrm{MPN} / 100 \mathrm{~g}$, where arugula, cucumber, and mint showed the highest FC mean values $\left(1 \times 10^{4}\right.$, $8 \times 10^{3}$, and $13 \times 10^{3} \mathrm{MPN} / 100 \mathrm{~g}$, respectively), whereas tomato samples had the lowest mean $850 \mathrm{MPN} / 100 \mathrm{~g}$. In accordance with the current results, heavy contamination with FCs between $4.0 \times 10^{3}$ and $9.3 \times 10^{8} \mathrm{MPN} / \mathrm{g}$ was also observed in a survey that was carried out in Ghana on some vegetables cultivated with poor-quality irrigation water ${ }^{[26]}$. In Ethiopia, Weldezgina and Muleta ${ }^{[19]}$ stated that MPN of total and FC and their overall mean in vegetables ranged from 865.3 to 1036.0 and 524.0 to $716.0 \mathrm{MPN} / 100 \mathrm{ml}$, respectively. In line with the present findings, in an early study conducted by Ashenaf ${ }^{[27]}$ in Ethiopia, raw consumed food like tomato had TC and FC counts of $1.5 \times 10^{3}$ and $3.7 \times 10^{2} \mathrm{MPN} / 10 \mathrm{~g}$, respectively.

Raw vegetables are widely consumed in the form of salads in most countries. They are considered to be suitable and convenient meals for today's lifestyles. In Egypt, RTE vegetable salad (known as green salad) is one 
of the most popular and widely consumed dishes in the Egyptians' daily food. RTESs are considered as a high-risk food because they do not require heating, and may not be cleaned or washed properly before consumption ${ }^{[13]}$.

Contamination of RTE foods sold in restaurant premises and by street vendors rendering them unacceptable for human consumption has become a global health problem. In this piece of work, 50 RTES samples were examined (28 from restaurants and 22 from street vendors).

The ACC mean value for the 22 street-vended RTESs was $4.1 \pm 1.0 \log C F U / g$. This was nearly similar to the results recorded by Amiko et al. ${ }^{[28]}$ in Ghana, where raw mixed vegetable salads obtained from five randomly selected vendors had a mean aerobic count of $\log _{10} 4.70$ $\mathrm{CFU} / \mathrm{g}\left(5 \times 10^{4} \mathrm{CFU} / \mathrm{g}\right)$. A higher count was reported earlier by Kubheka et al. ${ }^{[29]}$ in South Africa, as the 55 salads collected from street vendors had an ACC mean value of $5.9( \pm 0.6) \log \mathrm{CFU} / \mathrm{g}$ and the count ranged between 2.7 and $8.9 \log \mathrm{CFU} / \mathrm{g}$. Another higher ACC mean value was reported in a study done in India by Mritunjay and $\operatorname{Kumar}^{[30]}$, where a total of 480 samples of eight different raw salad vegetables from local markets had a mean AMC of $6.1 \mathrm{log} \mathrm{CFU} / \mathrm{g}$, ranging from 2.0 to $9.6 \log \mathrm{CFU} / \mathrm{g}$.

On the contrary, in this study, the ACC mean value for the 28 RTES samples purchased from restaurants was $7.5 \pm 1.4 \log \mathrm{CFU} / \mathrm{g}$, ranging from 3.8 to $9.4 \log \mathrm{CFU} / \mathrm{g}$. In concordance with the results in the present study, Pamuk et al. ${ }^{[31]}$ in Turkey reported that $55.1 \%$ of the RTES samples from different private restaurants, cafes, and shopping centers were found to have total viable counts of more than $6 \log$ CFU/g, and Jeddi et al. ${ }^{[32]}$ in Iran reported that the count of these bacteria in salads ranged from 5.5 to $7.4 \log \mathrm{CFU} / \mathrm{g}$.

In the present study, the ACC mean value of RTES from restaurants was significantly higher than that of street vendors. This may be the result of the greater number of people that can possibly be involved in the handling and preparation of this type of food in restaurants. In addition, street-vended foods are prepared and sold in the streets for immediate consumption, as there is usually a lack of storage facilities, whereas in restaurants, the salads are stored, and leftovers may be used for several days. The leftovers could serve as a good source for contaminating freshly prepared salads ${ }^{[32]}$. According to Frank-Peterside and Waribor ${ }^{[33]}$, bacterial load on vegetables increase with time during storage. It is advisable to separate the leftovers from freshly prepared salads to prevent cross contamination. The leftovers could be kept for sale the next day, only if they are kept under cold storage and then reheated above $70^{\circ} \mathrm{C}$ before being sold. However, as salads are generally not heated, it is advisable to discard any leftovers ${ }^{[34]}$. In agreement with the current findings, Khater et $a l .{ }^{[35]}$ in Egypt documented that salad samples obtained from restaurants had a higher ACC value than the street- vended ones (5.70 and $4.92 \log$ CFU/g, respectively). In contrast to these results, in Togo, Soncy et al ${ }^{[36]}$ reported that the microbial loads of salad samples from the street vendors in Lomé were higher than that of the studied Domino restaurant.

The present study showed that FC were detected in $90.1 \%$ of tested vegetable samples. On the contrary, $66 \%$ of the examined RTES samples were positive for FC (distributed as $30.0 \%$ RTES samples from restaurants and $36.0 \%$ RTES samples from street vendors). This was in accordance with the results of Gomez-Aldapa et al. ${ }^{[11]}$ in Mexico, who found that $95.5 \%$ of the 220 analyzed samples were contaminated with FC, and those of Cerna-Cortes et al $^{[37]}$, where $\mathrm{FC}$ were identified in $32 \%$ of 100 tested RTES samples (50 samples from different supermarkets and 50 from street-vendor stalls). Moreover, in Brazil, Froder et al. ${ }^{[9]}$ detected FC concentrations higher than $10^{2}$ CFU/g (Brazilian standard) in $73 \%$ of the samples, and Castro-Rosas et al. [4] reported that $99 \%$ of the 130 samples collected from restaurants in Mexico were contaminated with FC.

Over the past 10 years, there has been an increasing demand for RTE meals as people changed their eating habits because of healthier lifestyle interest. Nevertheless, RTE meals may be recognized as a source of food poisoning outbreaks in developed countries. Street foods are enjoying increasing patronage owing to industrialization which is forcing many city dwellers to eat their major daily meals out of home, as street food vendors provide cheap and enjoyable food to millions of consumers. In developing countries, street food vending is a common feature of most cities and towns ${ }^{[34]}$.

According to the Public Health Laboratories guidelines (PHLS) ${ }^{[16]}$ for the microbiological quality of some RTE foods, of the 50 examined RTES samples in this study, $54.0 \%$ in this study were satisfactory regarding ACC, $26 \%$ were acceptable, and $20.0 \%$ were unsatisfactory. Nearly similar results were reported by Hannan et al. ${ }^{[13]}$ in Pakistan, where $58 \%$ of the 50 tested salads from different vendors and restaurants showed satisfactory levels of ACC, $20 \%$ were on the borderline, whereas $22 \%$ had unsatisfactory levels.

Examination for the presence of pathogens in RTE food products contributes to food safety. Salmonella spp. is a common foodborne pathogen that causes food contamination, which has resulted in higher economic losses and poses a significant threat to public health. Salmonella spp. has been implicated in disease outbreaks associated with consumption of fresh and RTE vegetables ${ }^{[24]}$. In this piece of work, all the 121 studied samples were satisfactory regarding Salmonella spp., as it was not detected in $25 \mathrm{~g}$ of any of the samples. The current findings were in concordance with the results of many researchers from different countries, where Salmonella spp. 
were not detected in their samples: Soncy et al. ${ }^{[36]}$ in Togo, Allen et al. ${ }^{[38]}$ in Canada, Caponigro et al. ${ }^{[39]}$ in Italy and earlier, Sagoo et al. ${ }^{[8]}$ in the UK. It has been documented that negative results may suggest that levels of occurrence of these pathogens on the sampled population of RTES may be below the sensitivity of the used detection method and could be minimally affected by season and other considered factors ${ }^{[39]}$. In contrast to the present findings, Salmonella was detected in the samples examined by Weldezgina and Muleta $^{[19]}$ in Ethiopia, Gomez-Aldapa in Mexico ${ }^{[11]}$, and Toe et al. ${ }^{[40]}$ in the Ivory Coast with isolation percentages of $20.7 \%, 6.8 \%$ and $2.6 \%$, respectively.

As specified by PHLS guidelines ${ }^{[16]}$, RTE food products should contain less than $20 \mathrm{E}$. coli $\mathrm{CFU} / \mathrm{g}$ to be satisfactory. Accordingly, the current study showed that all the 71 fresh vegetable samples, together with all RTES (28) samples from restaurants, were satisfactory regarding E. coli $(<20 \mathrm{CFU} / \mathrm{g})$, whereas $81.8 \%$ RTES samples from street vendors were found to be satisfactory. In line with the findings in this study, Sagoo et al. ${ }^{[8]}$ revealed that the vast majority of their examined vegetable salads (99.3\%) were of satisfactory or acceptable microbiological quality based on the PHLS guidelines for some RTE foods sampled at the point of sale, whereas only $0.5 \%$ of samples were of unsatisfactory microbiological quality owing to E. coli. Moreover, earlier, Sagoo et al. ${ }^{[7]}$ stated that $98.5 \%$ of 3200 RTE organic vegetables were satisfactory, $1 \%$ acceptable, and $0.5 \%$ were of unsatisfactory microbiological quality according to the same guidelines. E. coli was detected in $1.5 \%$ (48/3200) of RTE organic vegetable samples, and was present at $10^{2} \mathrm{CFU} / \mathrm{g}$ or more in $0.3 \%$ samples. The presence of $E$. coli in food indicates recent direct or indirect fecal contamination and possible presence of other enteric pathogens known to be causative agents of foodborne gastroenteritis and bacterial diarrheal diseases ${ }^{[24]}$.

It is worth mentioning that in this study, $18.2 \%$ of streetvended RTES samples were significantly unsatisfactory regarding E. coli levels ( $>100 \mathrm{CFU} / \mathrm{g})$ compared with RTES from restaurants and fresh vegetables from markets. Unsanitary handling of street foods by some of the vendors has been commonly found to be the source of contamination. This could be attributed to the fact that most of the street vendors do not take the needed precautions to avoid contamination of the raw salads during preparation and sale, as they are usually unaware of food contamination causes. In addition, in many developing countries, street food vending activities are not usually protected or regulated by the governments. Furthermore, it has been previously noted that stands used by street vendors are usually of inefficient construction, running water is not easily accessible, and hand and dish washing are performed in the same bucket, sometimes without soap. Wastewater is usually discarded right there in the streets, and garbage is likewise conveniently discarded right next to the stands, providing attraction, food, and harborage for insects and rodents. In many cases, toilets are not available, thus forcing the vendors to eliminate their body wastes also in areas close by and to return to their vending sites without washing their hands. Such conditions and practices are likely to lead to cross contamination of street food, thus adequate measures for treatment and cleaning of raw materials, environment and utensils together with hygienic practices of vendors must be strictly implemented to ensure good quality of fresh vegetables and RTES and significantly reduce their contamination ${ }^{[34]}$.

\section{LIMITATIONS OF STUDY}

One of the limitations of this study was not testing for other foodborne pathogens such as Listeria monocytogenes. This would have added to the results in the present study, but unfortunately it was not feasible during the study period.

\section{CONCLUSION}

All examined samples were contaminated and yielded the growth of aerobic mesophilic bacteria with varying densities, where RTES samples purchased from restaurants had the highest ACC mean values compared with fresh vegetables from local markets and RTES from street vendors. Most fresh vegetables were contaminated with FC. According to the PHLS guidelines for the microbiological quality of some RTE foods, only street-vended RTES samples yielded unsatisfactory levels of E. coli.

The present findings highlight the importance of training restaurant staff regarding sanitary methods of salad preparation, together with avoiding long storage duration and usage of leftovers. Moreover, they emphasize the particular attention that should be paid to hygienic handling of raw vegetables to ensure that microbiological standards for managing vegetables are effectively followed. They also indicate the need for regular inspection and close supervision of handling practices and preparation methods of street-vended salads.

\section{ACKNOWLEDGEMENT}

The authors would like to express deepest thanks and sincere gratitude to Dr. Amira Amine, Dr. Faten Moustafa, and the technicians' staff at the Microbiology Department, High Institute of Public Health, Alexandria University for their kind help and appreciated efforts during the performance of the practical part of this study.

\section{CONFLICT OF INTEREST}

There are no conflicts of interest.

\section{REFERENCES}

1. Slavin JL, Lloyd B. Health benefits of fruits and 
vegetables. Adv Nutr 2012; 3: 506-516.

2. Olaimat AN, Holley RA. Factors influencing the microbial safety of fresh produce: a review. Food Microbiol 2012; 32:1-19.

3. Abdullahi IO, Abdulkareem S. Bacteriological quality of some ready to eat vegetables as retailed and consumed in Sabon-Gari, Zaria, Nigeria. Bayero J Pure Applied Sciences 2010; 3: 173-175.

4. Castro-Rosas J, Cerna-Cortés JF, Méndez-Reyes E, Lopez-Hernandez D, Gómez-Aldapa CA, EstradaGarcia T. Presence of faecal coliforms, Escherichia coli and diarrheagenic E. coli pathotypes in readyto-eat salads, from an area where crops are irrigated with untreated sewage water. Int J Food Microbiol 2012; 156: 176-180.

5. World Health Organization (WHO). Food safety Fact sheet No. 399; 2015. Available at: http://www.who. int/mediacentre/factsheets/fs399/en/. [Accessed 12 August 2017]

6. FAO/WHO. Microbiological hazards in fresh fruits and vegetables Food and Agriculture Organization of the United Nations FAO/WHO; 2008. Available at: http://www.who.int/foodsafety/publications/mra_14/ en/. [Accessed 12 August 2017].

7. Sagoo SK, Little CL, Mitchell RT. The microbiological examination of ready-to-eat organic vegetables from retail establishments in the United Kingdom. Lett Appl Microbiol 2001; 33: 434-439.

8. Sagoo SK, Little CL, Ward L, Gillespie IA, Mitchell RT. Microbiological study of ready-to-eat salad vegetables from retail establishments uncovers a national outbreak of salmonellosis. J Food Prot 2003; 66: 403-409.

9. Froder H, Martins CG, De Souza KL, Landgraf M, Franco BD, Destro MT. Minimally processed vegetable salads: microbial quality evaluation. J Food Prot 2007; 70: 1277-1280.

10. Faour-Klingbeil D, Todd ECD, Kuri V. Microbiological quality of ready-to-eat fresh vegetables and their link to food safety environment and handling practices in restaurants. LWT Food Sci Technol 2016; 2016: 224-233.

11. Gómez-Aldapa CA, Rangel-Vargas E, Castro-Rosas J. Frequency and correlation of some enteric indicator bacteria and salmonella in ready-to-eat raw vegetable salads from mexican restaurants. J Food Sci 2013; 78: M1201-M1207.
12. World Health Organization (WHO). 10 Facts on food safety. Updated October; 2016 Available at: http:// www.who.int/features/factfiles/food_safety/en/. [Accessed May 2017].

13. Hannan A, Rehman R, Saleem S, Khan MU, Qamar MU, Azhar H. Microbiological analysis of readyto-eat salads available at different outlets in Lahore, Pakistan. IFRJ 2014; 21: 1797-1800.

14. US Food and Drug Administration. BAM bacteriological analytical manual online. Center for Food Safety and Applied Nutrition. Available at: https://www.fda.gov/Food/FoodScienceResearch/ LaboratoryMethods/ucm2006949.htm. [Accessed April 2017].

15. Kotz S, Balakrishnan N, Read CB, Vidakovic B Encyclopedia of statistical sciences. 2nd ed. Hoboken, NJ: Wiley-Interscience; 2006.

16. Gilbert RJ, de Louvois J, Donovan T, Little C, Nye K, Ribeiro CD, et al. Guidelines for the microbiological quality of some ready-to-eat foods sampled at the point of sale. PHLS Advisory Committee for Food and Dairy Products. Commun Dis Public Health 2000; 3: 163-167.

17. Nguyen-the C, Carlin F. The microbiology of minimally processed fresh fruitsand vegetables. Crit Rev Food Sci Nutr 1994; 34: 371-401.

18. Khalil R, Gomaa M. Evaluation of the microbiological quality of conventional and organic leafy greens at the time of purchase from retail markets in Alexandria, Egypt.Pol J Microbiol 2014; 63:237-243.

19. Weldezgina D, Muleta D. Bacteriological contaminants of some fresh vegetables irrigated with Awetu River in Jimma Town, Southwestern Ethiopia. Adv Biol 2016; 2016: 1-11.

20. Nyenje ME, Odjadjare CE, Tanih NF, Green E, Ndip RN. Foodborne pathogens recovered from ready-toeat foods from roadside cafeterias and retail outlets in Alice, Eastern Cape Province, South Africa: Public Health Implications. Int J Environ Res Public Health 2012; 9: 2608-2619.

21. Buyukunal SK,Issa G,AksuF, Vural A. Microbiological quality of fresh vegetables and fruits collected from supermarkets in Istanbul, Turkey. J Food Nutrition Sci 2015; 3: 152-159.

22. Aycicek H, Oguz U, Karci K. Determination of total aerobic and indicator bacteria on some raw eaten vegetables from wholesalers in Ankara, Turkey. Int J 
Hyg Environ Health 2006; 209: 197-201.

23. Halablab MA, Sheet IH, Holail HM. Microbiological quality of raw vegetables grown in Bekaa Valley, Lebanon. Am J Food Technol 2011; 6:129-139.

24. Health Protection Agency. Guidelines for assessing the microbiological safety of ready-to-eat foods. London: Health Protection Agency; 2009.

25. Nguz K, Shindano J, Samapundo S, Huyghebaert A. Microbiological evaluation of fresh-cut organic vegetables produced in Zambia. Food Control 2005; 16: 623-628.

26. Amoah P, Drechsel P, Abaidoo RC, Ntow WJ. Pesticide and pathogen contamination of vegetables in Ghana's urban markets. Arch Environ Contam Toxicol 2006; 50: 1-6.

27. Ashenafi M. Microbial load, incidence and antibiotic resistance of some disease-causing microorganisms on raw food items in consumed Ethiopia. MIRCEN J Appl Microbiol Biotechnol 1989; 5:313-319.

28. Ameko E, Achio S, Alhassan S, Kassim A. Microbial safety of raw mixed-vegetable salad sold as an accompaniment to street vended cooked rice in Accra, Ghana. Afr J Biotechnol 2012; 11: 11078-11085.

29. Kubheka LC, Mosupye FM, von Holy A. Microbiological survey of street-vended salad and gravy in Johannesburg city, South Africa. Food Control 2001; 12: 127-131.

30. Mritunjay SK, Kumar V. A study on prevalence of microbial contamination on the surface of raw salad vegetables. Biotech 2017; 7:13.

31. Pamuk S, Gürler Z, Yildirim Y, Ertaş N. The microbiological quality of ready to eat salads sold in Afyonkarahisar, Turkey. Kafkas Univ Vet Fak Derg 2013; 19: 1001-1006.

32. Jeddi MZ, Yunesian M, Gorji ME, Noori N, Pourmand MR, Khaniki GR. Microbialevaluation of fresh, minimally-processed vegetables and bagged sprouts from chainsupermarkets. J Health Popul Nutr 2014; 32: 391-399.

33. Frank-Peterside N, Waribor O. Bacteria associated with spoilage of fluted pumpkins leaves and their effect on the chlorophyll content. Niger J Microbiol 2006; 20: 751-756.

34. Alimi BA. Risk factors in street food practices in developing countries: a review. Food Sci Hum Wellness 2016; 5: 141-148.

35. Khater DF, Heikal GE, Shehata AA, El-Hofy FI. The microbiological assessment of ready-to-eat-food (liver and kofta sandwiches) in Tanta City, Egypt. BVMJ 2013; 25: 187-197.

36. Soncy K, Anani K, Djeri B, Adjrah Y, Eklu MM, Karou DS, et al. Hygienic quality of ready-to-eat salads sold in the street and a modern restaurant in Lomé, Togo. IJBCS 2015; 9: 2001-2010.

37. Cerna-Cortes JF, Gómez-Aldapa CA, Rangel-Vargas E, Ramírez-Cruz E, Castro-Rosas J. Presence of indicator bacteria, Salmonella and diarrheagenic Escherichia coli pathotypes on mung bean sprouts from public markets in Pachuca, Mexico. Food Control 2013; 31:280-283.

38. Allen KJ, Kovacevic J, Cancarevic A, Wood J, Xu $\mathrm{J}$, Gill B, et al. Microbiological survey of imported produce available at retail across Canada. IntJ Food Microbiol 2013; 162:135-142.

39. Caponigro V, Ventura M, Chiancone I, Amato L, Parente E, Piro F. Variation of microbial load and visual quality of ready-to-eat salads by vegetable type, season, processor and retailer. Food Microbiol 2010; 27:1071-1077.

40. Toe E, Dadié A, Dako E, Loukou G. Bacteriological quality and risk factors for contamination of raw mixed vegetable salads served in collective catering in Abidjan (IvoryCoast). Adv Microbiol 2017; 7: 405-419. 